\title{
PENERAPAN ART THERAPY MEMBATIK COLET SEBAGAI UPAYA MEMELIHARA FUNGSI KOGNITIF LANSIA DI POSYANDU BAROKAH, KELURAHAN KLAMPIS NGASEM, KECAMATAN SUKOLILO, KOTA SURABAYA, PROVINSI JAWA TIMUR
}

\author{
THE APPLICATION OF ART THERAPY BATIK COLET AS AN EFFORT TO \\ MAINTAIN ELDERLY COGNITIVE FUNCTIONS IN POSYANDU BAROKAH, \\ KELURAHAN KLAMPIS NGASEM, KECAMATAN SUKOLILO, KOTA SURABAYA, \\ PROVINSI JAWA TIMUR
}

\author{
Elida Ulfiana ${ }^{1}$, Makhfudli ${ }^{2}$, Kusnul Chotimah ${ }^{3}$, Zenitha Rani ${ }^{4}$ \\ ${ }^{1,2,3,4}$ Universitas Airlangga , Surabaya \\ Email: elida_u@fkp.unair.ac.id
}

\begin{abstract}
ABSTRAK
Kelurahan Klampis Ngasem merupakan salah satu wilayah di Surabaya timur tepatnya di kecamatan Sukolilo kota Surabaya. Kelompok sasaran dalam program kemitraan masyarakat (PKM) ini adalah Posyandu Lansia “ Barokah" di RW 3. Permasalahan yang terjadi di Posyandu Lansia Barokah yakni kegiatan kurang variatif dan inovasi sehingga sebagian lansia kurang berminat dan bosan untuk mengikuti secara rutin yang ditunjukkan dengan kehadiran lansia $<75 \%$, belum adanya upaya pencegahan demensia yang dijalankan secara teratur dan continue bagi lansia, kurangnya pengetahuan lansia tentang perubahan fungsi kognitif dan upaya untuk memelihara fungsi kognitif sehingga mencegah dari demensia,dan tersedianya waktu luang lansia selain kegiatan rutin posyandu dan yang belum dimanfaatkan supaya bermanfaat dan produktif. Solusi untuk mengatasi permasalahan tersebut adalah melalui penerapan Art Therapy membatik colet. Tujuan pengabdian masyarakat ini untuk membantu mengekspresikan diri, memelihara fungsi kognitif lansia dan memberikan keterampilan baru dalam membatik sebagai kegiatan di Posyandu Lansia Barokah Kelurahan Klampis Ngasem. Kegiatan yang dilaksanakan adalah skrining untuk melihat fungsi kognitif lansia menggunakan Mini mental state examination (MMSE) dan clock drawing test (CDT), penyuluhan tentang pencegahan demensia yang mencakup mengenal demensia, pencegahan demensia, dan art therapy, pelatihan batik colet dengan metode demontrasi, dan simulasi. Hasil membatik colet akan di proses lagi dengan bantuan kader atau lansia yang memiliki ketrampilan menjahit untuk dijadikan sarung bantal sofa. Dari proses ini maka akan dihasilkan sebuah karya atau produk hasil dari metode membatik colet.
\end{abstract}

Kata Kunci :art therapy membatik colet, fungsi kognitif, lansia

\begin{abstract}
Klampis Ngasem is one of the areas in East Surabaya, precisely in Sukolilo sub-district, Surabaya. The target group in the community partnership program (PKM) is the Elderly Posyandu "Barokah" in RW 3. Problems that occur in the Elderly Barokah Posyandu are less varied activities and innovation so that some elderly are less interested and bored to follow routinely as indicated by the presence of the elderly $<75 \%$, the absence of efforts to prevent dementia that is carried out regularly and continue for the elderly, lack of elderly knowledge about changes in cognitive function and efforts to maintain cognitive function so as to prevent dementia, and the availability of leisure time for the elderly in addition to routine posyandu activities and those that have not been utilized to be useful and productive. The solution to overcome these problems is through the application of Art Therapy to make colet batik. The purpose of this community service is to help express themselves, maintain the cognitive function of the elderly and provide new skills in making batik as an activity in the Posyandu Elder Barokah Klampis Ngasem Village. The activities carried out are screening to see the cognitive function of the elderly using Mini mental state examination (MMSE) and clock drawing test (CDT), counseling about prevention of dementia which includes knowing dementia, prevention of dementia, and art therapy, batik colet training with demonstration methods, and simulation. The results of batik colet will be processed again with the help of cadres or the elderly who have sewing skills to be used as sofa pillowcases. From this process, a work or product will be produced from the batik colet method.
\end{abstract}


Keywords : art therapy batik colet, cognitive functions, elderly

\section{PENDAHULUAN}

Kelurahan

Klampis Ngasem

merupakan salah satu wilayah di Surabaya timur tepatnya di kecamatan Sukolilo kota Surabaya. Jumlah penduduk di kelurahan Klampis Ngasem seluruhnya 17.251 terdiri dari laki-laki 8.803 dan perempuan 8.448 yangbtertampung dalam $5.565 \mathrm{KK}$. Luas wilayah kelurahan Klampis Ngasem 157.915 Ha yang mencakup 9 RW dan 48 RT. Mayoritas warga bekerja sebagai karyawan swasta, hal ini seiring dengan perkembangan bidang perekonomian, terutama perdagangan yaitu dengan banyaknya pusat pertokoan swalayan, ruko, dan pedagang-pedagang perseorangan baik besar maupun kecil banyak ditemui di wilayah kelurahan Klampis Ngasem (Ngasem, 2019)

Kelompok sasaran dalam program kemitraan masyarakat (PKM) ini adalah Posyandu Lansia “ Barokah" di RW 3 Kelurahan Klampis Ngasem yang mencakup wilayah di Jl. Klampis Semalang gang $1,2,3,4,5,6,7,8$. Sebagian dihuni oleh penduduk asli dan sebagian dihuni penduduk tidak tetap. Posyandu Lansia " Barokah" dikelola oleh 5 orang kader posyandu dan beranggotakan 55 lansia di RW 3. Selain 55 orang yang terdaftar di posyandu tersebut, masih ada lansia yang yang tidak terdaftar dan tidak mengikuti posyandu lansia karena alasan mengalami penyakit kronis sehingga tidak mampu mandiri berjalan sampai kondisi imobilisasi, dan juga karena tidak bisa meninggalkan rumah karena harus mengurus pekerjaan rumah tangga dan keluarga.

Posyandu lansia " Barokah" berdiri sejak 3 tahun yang lalu dan merupakan binaan dari Puskesmas Klampis Ngasem kecamatan Sukolilo. Posyandu lansia ini telah melaksanakan program Puskesmas dengan melaksanakan 5 program kegiatan yang rutin setiap bulannya yaitu pemeriksaan kesehatan, pengajian / istiqosah, penyuluhan kesehatan, senam lansia, dan pemberian makanan tambahan. Namun, sampai saat ini partisipasi lansia untuk hadir di kegiatan posyandu lansia semakin menurun bahkan $<75 \%$, terutama pada kegiatan pengajian, senam, penyuluhan rata-rata hanya sekitar 30 orang ( 55\%-60\%) lansia yang hadir. Padahal lansia di RW 3 ini sudah tidak bekerja, sehingga mereka hanya beraktivitas di rumah.

Berdasarkan wawancara dengan ibu Nurbiyantari selaku ketua posyandu mengungkapkan beberapa alasan lansia tidak hadir karena ada yang lupa jadwal kegiatan, sebagian malas untuk datang, dan sebagian kecil karena kesibukan pekerjaan rumah. Alasan lupa merupakan menunjukkan bahwa lansia telah mengalami tanda gejala penurunan kognitif terutama kemampuan orientasi. Alasan malas untuk datang merupakan cerminan rendahnya minat untuk kegiatan di posyandu, dan hal ini bisa karena kebosanan dengan kegiatan rutin yang monoton. Bila kondisi situasi ini dibiarkan, maka dapat menyebabkan menurunnya status kesehatan lansia, semakin sepat mengalami demensia serta dapat menurunkan kualitas hidup lansia.

Permasalahan yang terjadi di Posyandu Lansia Barokah adalah kegiatan di Posyandu Lansia Barokah yang monoton, kegiatan kurang variatif dan inovasi sehingga sebagian lansia kurang berminat dan bosan untuk mengikuti secara rutin yang ditunjukkan dengan kehadiran lansia $<75 \%$, belum adanya upaya pencegahan demensia yang dijalankan secara teratur dan continue bagi lansia, kurangnya pengetahuan lansia tentang perubahan fungsi kognitif dan upaya untuk memelihara fungsi kognitif sehingga mencegah dari demensia, dan tersedianya waktu luang lansia selain kegiatan rutin posyandu yang belum dimanfaatkan supaya bermanfaat dan produktif.

Solusi untuk mengatasi permasalahan tersebut adalah melalui kegiatan Art Therapy membatik colet yang akan dilaksanakan melalui penyuluhan, pelatihan batik colet, pembuatan batik colet, pengukuran fungsi kognitif lansia. Malchiodi (2013) menyatakan art therapy adalah suatu bentuk terapi yang bersifat ekspresif dengan mengunakan materi seni, seperti lukisan, kapur,spidol, dan lainnya. 
Tujuan kegiatan art therapy yaitu untuk membantu mengekspresikan diri, meningkatkan keterampilan coping individu, mengelola stress, memperkuat rasa percaya diri, memelihara fungsi kognitif, dan mencegah demensia.

\section{METODE PELAKSANAAN}

Tahapan yang dilaksanakan pada kegiatan pengabdian masyarakat ini adalah persiapan, pelaksanaan, dan evaluasi. Pada tahap persiapan dilaksanakan kegiatan koordinasi tim pengabdian masyarakat, menyusun pengorganisasian pelaksanaan \& pembagian tugas tim, mempelajari tahapan cara membatik colet dari video tutorial dan dari ahli batik, menyiapkan peralatan dan bahan membatik colet, menyiapkan materi edukasi, dan mengurus perijinan pelaksanaan kegiatan ke Puskesmas, Kelurahan Klampis Ngasem, dan koordinasi dengan kader Posyandu Lansia Barokah.

Pada tahap pelaksanaan, dilaksanakan beberapa kegiatan antara lain skrening pengukuran fungsi kongnitif lansia, edukasi pencegahan demensia, pelatihan batik colet, dan pembuatan batik colet.

Metode yang digunakan dalam kegiatan skrining fungsi kognitif lansia yaitu menggunakan MMSE (Mini Mental State Examination) dan CDT (Clock Drawing Test) yang bertujuan untuk mengukur fungsi kognitif lansia. Dalam kegiatan edukasi pencegahan demensia, metode penyuluhannya yang digunakan adalah ceramah dan tanya jawab. Metode ceramah merupakan metode dengan menyampaikan informasi dan pengetahuan secara lisan (Susilowati, 2016). Media yang digunakan adalah leflet yang di desain menyesuaikan lansia. Materi tentang mengenal demensia, upaya pencegahan, art therapy.

Kegiatan pelatihan batik colet merupakan kegiatan melatih lansia dan kader untuk membatik colet. Metode yang dilakukan adalah demonstrasi dan simulasi. Media yang digunakan adalah peralatan dan bahan membatik; kain, meja, canting, pewarna remasol, waterglass, kuas, meja / alas. Dalam kegiatan membuat batik colet merupakan kegiatan yang menerapkan art therapy membatik colet kepada lansia. Proses pembuatan batik tersebut memberikan kesempatan setiap lansia untuk menggambar pada selembar kain, dan mewarnai menggunakan zat pewarna kain (Remasol) warna sesuai keinginan. Setelah proses tersebut, selanjutnya adalah proses pencucian dan penjemuran kain. Setelah selesai akan dilanjutkan untuk pemanfaatan kain dengan bantuan kader atau lansia yang memiliki ketrampilan menjahit dijadikan sarung bantal sofa.

Evaluasi kegiatan pengabdian masyarakat dilakukan dengan berbagai metode antara lain Quiz, observasi, tes MMSE, dan wawancara. Evaluasi menggunakan metode Quiz bertujuan untuk mengukur pengetahuan lansia tentang pencegahan demensia. Metode Observasi untuk mengevaluasi proses pelaksanaan setiap kegiatan. Tes MMSE bertujuan untuk mengevaluasi fungsi kognitif lansia. Metode wawancara bertujuan untuk mengetahui testimoni dari perwakilan lansia dan kader posyandu

\section{HASIL DAN PEMBAHASAN}

\section{Persiapan}

Dalam tahap persiapan dilaksanakan koordinasi Tim dengan Kader di Posyandu Lansia Barokah. Kegiatan yang dilaksanakan adalah melakukan rapat koordinasi untuk identifikasi kebutuhan peralatan dan bahan penerapan art therapy membatik colet. Peralatan dan bahan terdiri dari : kain putih, kompor listrik untuk batik, canting, lilin malam, serbuk pewarna, waterglass, plastik, baskom, dll, melakukan koordinasi dengan kader Posyandu Barokah RW 3 Kelurahan Klampis Ngasem untuk penjadwalan kegiatan pengabdian Masyarakat. Adapun kesepakatan pelaksannan Skrining fungsi kognitif pada hari kamis tanggal 5 September 2019 sedangkan kegiatan penyuluhan dan membatik disepakati pada hari kamis tanggal 12 September 2019. Setelah itu, kegiatan yang dilaksanakan adalah koordinasi tim untuk penyusunan materi penyuluhan kepada lansia. Materi terdiri dari perubahan fungsi koqnitif lansia, dan cara-cara memelihara fungsi koqnitif, serta membatik colet. 


\section{Screening Fungsi Kognitif Lansia}

Pelaksanaan kegiatan screening fungsi kognitif lansia dilaksanakan pada hari kamis tanggal 5 September 2019. Metode screening yang digunakan adalah menggunakan tes MMSE dan CDT. Peserta yang tidak memiliki riwayat sekolah diberikan tes CDT sedangkan yang memiliki riwayat pernah sekolah diberikan tes MMSE. Adapun peserta yang datang dalam pelaksanaan screening berjumlah 18 lansia. Hasil screening menunjukkan mayoritas lansia memiliki fungsi kognitif yang baik, dan 4 lansia memiliki masalah pada koqnitif. .Diakhir kegiatan screening, para lansia diajak untuk mengisi TTS bersama-sama. TTS berisi beberapa pertanyaan yang mudah untuk dijawab lansia. Peserta lansia dibagi menjadi dua kelompok.

\section{Edukasi Pencegahan Demensia}

Pelaksanaan edukasi pencegahan demensia dilaksanakan pada hari kamis tanggal 12 September 2019. Materi yang diberikan pada kegiatan tersebut antara lain mengenal demensia, upaya pencegahan, art therapy. Metode penyuluhan yang digunakan adalah ceramah dan tanya jawab. Media yang digunakan adalah leflet yang di desain menyesuaikan lansia.

\section{Kegiatan Membatik Colet}

Pelaksanaan kegiatan membatik colet dilaksanakan pada hari kamis tanggal 12 September dan 3 Oktober 2019. Dalam kegiatan ini, lansia diajarkan cara membuat batik colet. Membatik colet adalah proses membatik tulis dengan metode mencolet dalam proses pewarnaan (Endriyani, 2015).

Metode yang digunakan pada pengabdian masyarakat ini antara lain simulasi, dan demonstrasi. Proses yang dilakukan dalam kegiatan adalah membuat pola, mencanting, dan mewarna hasil cantingan dengan teknik colet. Pelatihan dihadiri sebanyak 38 lansia. Kegiatan diawali dengan pengenalan alat, bahan dan proses membatik, kemudian lansia dibagi menjadi 3 kelompok yaitu kelompok pola, canting dan mewarnai. Telah dihasilkan 10 lembar kain batik colet dengan pola gambar alat transportasi, bunga, buah-buahan, dan nuansa ikan bawah laut. Kegiatan membatik ini merupakan salah satu penerapan aert therapy. Art therapy adalah bentuk terapi yang dilakukan dengan menggunakan potensi manusia agar dapat menjadi lebih kreatif melalui proses menghasilkan suatu karya seni (Ni, 2017).

Proses membatik ini dapat menstimulasi koqnitif lansia, proses menggambar bagianbagian dari tanaman bunga, buah, dan alat transportasi dapat mengaktifkan kemampuan orientasi, registrasi dan memori. Berdasarkan penelitian erwanto dan amigo (2017) menunjukkan peningkatan skor MMSE pada lansia setelah diberikan intervensi menggambar dan mewarnai. Kegiatan menggambar atau mewarnai dapat mendorong proses berfikir kreatif dan meningkatkan daya ingat lansia. Oleh karena itu, kegiatan tersebut sangat bermanfaat bagi lansia untuk mencegah demensia.

Selama proses menggambar ataupun mewarnai ini lansia dapat menceritakan pengalaman saat mengendarai alat-alat transportasi seperti bis, becak, mobil, dan hal ini membangkitkan memori lansia. Seperti pada salah satu lansia menggambar pola alat transportasi inisambil bercerita " saya dulu pernah naik bis waktu pulang ke rumah orang tua saya di Blitar, saat itu saya ajak anak saya masih kecil naik bis seneng sekali”.

Pada aspek registrasi, pada saat lansia menggambar, mencanting, maupun mewarnai pada kain, maka lansia melakukannya secara bertahap pada tiap bagian. Contohnya menggambar sepeda, lansia mengidentifikasi dengan menyebutkan bagian-bagian sepeda roda, sadel, pedal, dll.

\section{KESIMPULAN}

Dari kegiatan pengabdian masyarakat yang telah dilaksanakan dapat disimpulkan sebagai berikut:

1.Kegiatan pengabdian masyarakat yang dilakukan terhadap mitra Posyandu Lansia Barokah di Kelurahan Klampis Ngasem sangat membantu terutama dalam memberikan variasi dan inovasi kegiatan baru di Posyandu. 
2.Kegiatan penerapan art therapy membatik colet merupakan salah satu upaya yang dapat dilakukan untuk mencegah demensia jikalau dijalankan secara teratur dan terus-menerus.

3.Edukasi pencegahan demensi memberikan manfaat bagi lansia untuk meningkatkan pengetahuan lansia tentang perubahan kognitif dan upaya yang dapat dilakukan untuk mencegah demensia.

\section{DAFTAR PUSTAKA}

Endriyani. (2015). Upaya meningkatkan ketrampilan mencolet dan hasil belajar membatik melalui model pembelajaran contextual teaching and learning berbantuan video. Scholarian, Vol.5, No.2.

Erwanto, Rizky Erwanto., Amigo, Thomas Aquino Erjinyuare. (2017) Efektifitas Art Therapy dan Brain Gym Terhadap Fungsi
Kognitif Lansia.Jurnal Kesehatan, Vol 10 No 2.

Ngasem, M. K. K. K. (2019). Laporan KKN Tematik 59 Universitas Airlangga. Surabaya: LPM UNAIR.

Ni, I. (2017). Kajian teoritis penggunaan art therapy dalam pelaksanaan layanan bimbingan dan konseling di SMK Isna $\mathrm{Ni}$ ' matus Sholihah (pp. 173-182).

Permatasari E, Samsunuwiyati, Suparman M. (2017)' Penerapan Art Therapy untuk Menurunkan Depresi pada Lansia. Jurnal Muara Ilmu Sosial, Humaniora, dan Seni Vol. 1, No. 1, April 2017: hlm 116-126

Susilowati, D. (2016) Promosi kesehatan. Jakarta: BPPSDMK Kementerian Kesehatan RI. 